\title{
How far has the state 'stepped back': an exploratory study of the changing governance of higher education in China (1978-2018)
}

\author{
Shuangmiao $\mathrm{Han}^{1} \cdot \mathrm{Xin}_{\mathrm{Xu}^{2}}$ (D)
}

Published online: 22 March 2019

(C) The Author(s) 2019

\begin{abstract}
Due to the politicisation of universities-within-the-state, the state's governance of higher education in China differentiates itself from other countries. This study examines how the Chinese central government adjusts its governance over universities between 1978 and 2018. Based on an extensive analysis of policy documents and scholarly research, this study proposes an analytic framework, comprising the state's governance logics, governance instruments, and institutional demonstrations. The three strategically selected governance instruments, i.e. laws, policies, and finance, are demonstrated through various aspects integral to China's higher education - the dual-goverance structure, appointment of the principal leadership, access to higher education, university and discipline structures, curriculum and ideology, funding and grants, and tuition fees. Based on an in-depth investigation, the study argues that the underlying governance logics of the state are moving from direct controls to indirect supervision; however, despite the increasing university autonomy and academic freedom in some areas, the state has never abdicated the essential power and authority over higher education institutions. This paper contributes to the theoretical and practical understanding of China's governance of higher education in recent decades.
\end{abstract}

Keywords Higher education governance $\cdot$ State and university $\cdot$ Higher education policy $\cdot$ University autonomy $\cdot$ China

\section{Introduction}

The issue of governance is at the heart of higher education (HE) research (McDaniel 1996). With the increasing development of neo-liberalism and globalisation, governments around the

$\mathrm{Xin} \mathrm{Xu}$

xin.xu@education.ox.ac.uk

1 College of Education, Zhejiang University, Hangzhou, China

2 Department of Education, University of Oxford, Oxford, UK 
world have attempted to devolve more power to individual higher education institutions (HEIs) while taking a more supervisory role (Boer and File 2009; Mok 2002).

China has witnessed a similar trend, particularly after the Reform and Opening-up in the late 1970s (Ngok 2007; Wang 2010b). Since the publication of The Decision of the Reform of Education System by the Central Committee of the Communist Party of China (The Decision) in 1985, university autonomy has become a central concern in China's policy-making, scholarly research, and public debates. The Decision explicitly pointed out that the government shall grant power to HEIs, allowing them to have 'more autonomy in enrolment, finance, and decision-making' (Communist Party of China Central Committee 1985). Subsequent policy documents and laws all pointed to the importance of university autonomy and a supervisory state (e.g. Higher Education Law 1998; The Outline of China's National Plan for Medium and Long-term Education Reform and Development 2010).

With the decentralised polity orientation, China's HE governance has been moving from 'state control' to 'state supervision', rendering a higher level of university autonomy (Mok 2002; Yang et al. 2006). However, scholarly debates in the 2000s suggested a tension between autonomy and accountability, as well as a paradoxical combination of decentralisation and recentralisation of the state's power in China's HE (e.g. Hawkins 2000; Mok 2002; Yang et al. 2006). University administrators and scholars also reported constraints in certain areas of practices, despite a perceived increase in institutional autonomy and individual academic freedom (Yang et al. 2006). In December 2016, the present President Xi reaffirmed the party's leadership and political ideologies of HEIs in a high-profile speech. He claimed that universities 'must adhere to correct political ideologies' and become 'strongholds that adhere to the Party's leadership', possibly signalling the state's wresting back control over HE (Phillips 2016).

As a form of 'political exercise' (Marginson 1999; Kazamias 2009), China's HE is subject to its particular political and historical configurations. The primary goal of Chinese universities is nation building, demonstrated by various terms used in state narratives such as maintaining political stability, achieving economic modernisation, preserving cultural integrity, and enhancing national identity (Law 2014). Due to the high level of politicisation of universities-within-the-state, the state's governance of HE in China differentiates itself from other countries. This study reviews the development of HE governance in China since 1978 and explores the changing governance practices by investigating the following research question:

How has the state adjusted its governance of higher education in China between 1978 and $2018 ?$

Through in-depth document analysis, this study proposes an analytic framework to explore the governance logics and instruments employed by the state to steer HE in China. The paper explores institutional demonstrations of the proposed instruments, with a focus on public universities. It also contextualises the development of HE governance in China and discusses how those governance instruments have changed in line with socio-political reforms in the past three decades.

\section{A review of higher education governance}

Governance refers to "the structure of relationships that bring about organisational coherence, authorise policies, plans and decisions, and account for their probity, responsiveness and cost- 
effectiveness' (Gallagher 2001, p. 49). This 'deliberately looser' term (compared with 'government') allows 'more balance among the involved actors, more deliberative democracy and co-production of public policies among more diverse and equal actors' (Ferlie et al. 2008, p. 337). The state-university relationship particularly concerns the top-down authority exercised by the government (De Boer et al. 2008). Thus, this paper strategically focuses on the state's governance over universities.

Nation states' governance over universities has experienced substantive changes. In the early twentieth century, some universities transformed from self-sustainable institutions for higher learning to public institutions under the provision of state finance. Gradually, tension arises between universities' 'public accountability' and 'institutional autonomy'. On the one hand, the state expects universities to advance knowledge and produce labour forces while assuring the equality, equity, and quality of HE (Gallagher 2001). Demands for such public accountability are particularly high among critics claiming universities' lack of management competencies, self-indulgent nature, inherent inefficiency, irresponsibility, and irrelevance to social and economic needs (Gallagher 2001; Ferlie et al. 2008). On the other hand, universities actively seek the freedom necessary for their pursuit of truth and academic integrity, especially from political interference (Berdahl 1990; Kogan and Hanney 2000). The state responds to such conflicts by employing new governance strategies such as new intermediary bodies and performance-based funding (Capano and Turri 2016; Schwarz and Westerheijden 2004). In general, there is a shift from interventionist to evaluative governance, from rules to regulation and from 'ex ante control to ex post performance monitoring' (Enders et al. 2013, p. 10). In this sense, institutional autonomy exercises within the frameworks of state-controlled parameters and the managerial functions of funding bodies (Salter and Tapper 1994).

Moreover, this study argues that the concept of 'autonomy' appears ambiguous and largely culture-bound, and that China's model is different from its western counterparts, where university autonomy and academic freedom are coordinated through the interplay between the state, market, and academic oligarchy (Clark 1983). The western concept of university autonomy refers to the power for a university to govern without external control - institutional dependence, self-governance, and academic freedom completely free from the state control (Berdahl et al. 2005). In the Chinese context, 'autonomy' is often translated as 'zizhu', which more precisely refers to 'self-mastery' - being able to initiate its own agendas while supporting the state (Hayhoe and Liu 2010). Pan (2009) points out that Chinese universities and scholars are quite comfortable with the idea of 'semi-dependence', being neither distinctively separated from the state nor completely under its control. The balance between individualism and collectivism (Halstead and Zhu 2009) echoes Zha's (2012) argument that the perceived aim of Chinese scholars is to actively seek 'a high level of articulation between their academic pursuits and the national interest' (p. 209). The different understandings and connotations of 'autonomy' make the case of Chinese HE theoretically and practically intriguing, of which a discussion on China's governance must take account.

\section{Theoretical and methodological considerations}

A review of the literature reveals various ways for the state to govern and influence universities in varying contexts over different periods (e.g. Berdahl 1990; Gallagher 2001; Edirisooriya 2003; Mok and Lee 2003; Wang 2010b). This study draws on theoretical conceptualisation 
and empirical case studies well grounded in the existing literature, and resorts to an analytical simplification in understanding the governance strategies in Chinese HE. This study develops and proposes an analytic framework comprising the state's governance logics, instruments, and demonstrations (as shown in Fig. 1).

Here, 'governance logics' is defined as the overarching and underlying principles in HE governance, which guide the approaches and strategies employed by the state to steer HE. This paper explores the changes in the governance logics in China, through a detailed analysis of various government instruments and institutional demonstrations.

'Governance instruments' in this study refer to strategies employed by the government to control or influence the practice of HE under a certain logic of governance. 'Demonstrations' refer to institutional settings and practices placed through the guidance of various instruments. Through in-depth document analysis of policy papers and secondary literature, this study proposes three instruments of great importance in the Chinese context: law, policy, and finance. It further investigates the use of the three instruments in the HE sector as demonstrated by various institutional cases in the past three decades.

Law As the determining authority in the social formation and transformation, the state constantly uses legal interaction, a direct and visible strategy, to set boundaries for the operation of modern universities. Since the introduction of the market forces into HE, the state has become increasingly aware of using legislation to 'regulate new social relationships, practices and behaviors' (Law 2002, p. 579). The state's employment of laws to steer HE can take various forms, such as demonstrated in the framework: Chinese government uses laws to regulate the dual-governance structure in HEIs and legitimates its power to appoint university leadership such as vice chancellors.

Policy Government policies supplement laws and serve as continuous guidance to HE. This is particularly true for China's 'documentary politics' (Wu 1995, p. 24), which points to the country's long-standing tradition of using government documents to rule over national affairs (Jing 2013). This is evidently demonstrated in three areas proposed in the framework: the access to HE, the disciplinary structure, and the curriculum and ideology.

Finance The nature of an institution of higher learning is largely determined by the degree of its financial dependency on the state (Edirisooriya 2003). Therefore, as the dominant purchaser of university services (Crewe 2013) and/or the principal funding provider for public universities, the state can use financial measures to steer HE. A representative case in Chinese HE is the employment of funding strategies to monitor university performance. The study also discusses the government's control over the tuition fees.

This study investigates these three types of governance instruments to trace the trajectory of the state's governance of $\mathrm{HE}$ and explores their various institutional demonstrations that

Logics

Fig. 1 An analytic framework of China's higher education governance 
influence the university's everyday practice. The research primarily relies on document analysis. The first type of documents consists of 29 important governmental documents in China's HE, including laws, policy papers, and yearbooks. To complement the official documents and avoid the pitfall of confounding the 'stipulated autonomy' with the 'given autonomy' (Li and Yang 2014, p. 27), this study also examines scholarly research, especially empirical evidence on HE governance in China.

\section{China's governance of $\mathrm{HE}$}

Based on the framework, this section focuses on how the state uses different instruments to exercise power and authority over universities, and whether the state's governance has changed in line with changing social contexts in China between 1978 and 2018.

\section{Governance through law}

Before the late 1970s, except for several clauses in the Constitution and several administrative documents from the State Council, there was no legal framework for education in China. The year 1995 witnessed the publication of the first Education Law, which proposed fundamental principles for the national education system, educational institutions, educators, and educatees (Education Law 1995). The Higher Education Law was then promulgated in 1998, which consolidated the existing reforms that took place in HE since 1978, such as marketisation and the introduction of the tuition fee (Law 2002). The amendment of Higher Education Law in 2015 further highlighted the marketisation of HE in China. For instance, it deleted the regulation that HEIs 'may not be established for the purposes of making profits' (Higher Education Law 1998, article 24). Furthermore, it reframed the definition of the funding system of HE, changing from 'government financial allocation as the main source, supplemented by HEIs' fund-raising through various other channels' to 'founders' investment as the main source, with educatees sharing the costs and HEIs raising funds through various other channels' (Higher Education Law 1998, 2015, article 60).

The shift from lawlessness to establishing HE legal systems corresponds to Chinese government's intention to move away from 'rule of ruler' to 'rule of law' (Law 2002, p. 597), with an underlying purpose to transfer the governmental and institutional rulers' power to laws. However, those laws demonstrated a tension between decentralising the state's responsibilities and maintaining the state's control over HE.

On the one hand, the law legalised a devolvement of power from the central government to local governments, universities, and non-state sectors. For instance, the Higher Education Law stipulated that provincial governments shall coordinate and administer their local HEIs (1998, article 13), and that the state shall encourage all social sectors to run HEIs and 'to participate in and support the reform and development of HE' (1998, article 6). Universities were also designated as independent legal entities (Zha 2011), with autonomy in areas such as teaching, research, admission, international exchange and cooperation, management of facilities and finances, administration of faculty and students, and restructure of internal governance (Higher Education Law 1998; Li and Yang 2014).

On the other hand, the law legitimated the state's macro control over HE and its rights to demand institutional accountability. For instance, although local governments and non-state actors were invited to supervise and run HEIs, the law mandated the state's ultimate authority 
in clauses like 'the state adheres to the guidance of Marxism-Leninism, Mao Zedong Thought, and Deng Xiaoping Theory and follows the basic principles established by the Constitution to develop socialist higher education' (Higher Education Law 1998, 2015, article 3), 'the State Council shall provide unified guidance and administration for HE throughout the country' (Higher Education Law 1998, 2015, article 13), and that the formation of HEIs 'shall be subject to approval of the State Council' (Higher Education Law 1998, 2015, article 29). In addition, the concept of accountability was introduced in the legal framework as a trade-off for the idea of institutional autonomy. For instance, universities were required by the Higher Education Law to be accountable in sponsorship, the management of human and material resources, curriculum, research and innovation, social services, and international collaborations (Law 2002).

Such conflict of decentralisation and centralisation can be further illustrated by the fact that the state utilises legal powers to supervise universities' leadership. As legitimated by respective laws, the state not only introduced a dual-governance structure in universities, but also maintained the rights to appoint principal leadership.

\section{A dual-governance structure}

One of the most distinctive characteristics of Chinese universities, compared with its western counterparts, is its dual-governance structure, termed in the Higher Education Law (1998) as the 'presidential responsibility system under the leadership of the Party Committee' (article 13). It refers to the coexistence of an administrative system chaired by a president, and a party system embodied as a party committee, in a public university. In practice, the president and the administrative system undertake 'overall responsibility for the institution's teaching, research and administrative affairs' (Higher Education Law 1998, article 41); the party committee exercises unified leadership, supports the presidents, and ensures that the institution operates in line with the principles and policies of the party (Higher Education Law 1998, article 39).

An experimental reform of the dual-governance system was initiated in 1985, along with the efforts put forward by the Decision to devolve more autonomy to institutions. It appointed some universities to try out a sole 'president responsibility system' (Communist Party of China Central Committee 1985). The experiment was later abolished. The 'presidential responsibility system under the leadership of the Party Committee' was reaffirmed and became the standard governance form in China's public universities. A recent case was the Southern University of Science and Technology in Shenzhen. When it was opened in 2011, the university was an experimental point with only a president and no party secretary (the head of the party committee). However, the Communist Party of China Central Committee emphasised the guidance of the party committee for the university in 2011. The university later welcomed its first party secretary in 2014 (Southern University of Science and Technology 2018).

Although the Higher Education Law mandated that the two parts should operate independently and separately, in reality, the party's 'political authority is much higher and larger than the administrative authority' (Wang 2010a, p. 13). This 'politicised' university governance (Zha 2012, p. 209) causes constant questions about the overemphasis of party leadership over academic practices in universities. Legitimated by the Higher Education Law, the practically ambiguous boundary of the decision-making authority is a distinctive feature of Chinese universities, as well as one of the dominant ways for the state to exert its influence. 


\section{Appointment of the principal leadership}

Before the early 1980s, the appointment and promotion of personnel in public universities were completely controlled by the central government. In 1998, the Higher Education Law stated that the 'presidents and vice-presidents of HEIs shall be appointed and removed according to the relevant regulations of the state' (article 40), and one of the duties of presidents was to 'nominate candidates for vice-presidents, and appoint and remove directors of departments of the institution... appoint and dismiss teachers and other workers of the institution' (article 41).

The power of appointing presidents and party secretaries is held within the state bureaucracies, thus the power of ultimate decision-making in HEIs. For universities administered by the Ministry of Education (MoE) and provincial governments, the appointment of the two heads is announced respectively by the Organisation Department of the Communist Party of China (ODCPC) and the provincial party committee. Such arrangement stems from the fact that the position of Chinese public universities leaders corresponds to the state administrative ranking system. For example, for universities under the direct administration of the MoE, the president's administrative rank equals sub-provincial/ministerial level; the ODCPC is in charge of people with such rankings.

Hence, controlling the appointment of presidents and party secretaries, especially those of key research universities, and endowing the two positions with both political and administrative authorities over university affairs, is another legalised method for the state to exercise its power over HEIs.

\section{Governance through policy}

In the Chinese context, policy documents such as decisions, instructions, opinions, regulations, notices, and explanations issued by the National People's Congress, the Central Committee of the Communist Party of China, the State Council and other state agencies all have a law-binding effect (Law 2002). Some of them signal the central government's latest grand policy intentions, such as The Outline in 2010 and The Plan of Building World-class Universities and First-class Disciplines (State Council 2015); and some act as direct and timely tools for the state to monitor HE's operation, such as the notices and opinions published each year by the Ministry of Education on college admission (for example Ministry of Education 2003a, 2016a, b). This study examines the state's use of policy instruments to steer HE with focuses on the access to $\mathrm{HE}$, university and disciplinary structures, and university curriculum.

\section{Access to $\mathrm{HE}$}

The majority of Chinese high school graduates must pass the Gaokao (the Chinese national college entrance examination) to be enrolled in HEIs (Higher Education Law 1998, article 19). Ever since its establishment in 1952 (disrupted during the Cultural Revolution and restored in 1977), the content and procedure of Gaokao have been under the control of the state (Ngok 2008; Liu 2015b) and under the constant influence of government policies (for example Ministry of Education 2003a, 2016b, d).

One significant trend of Gaokao reform is to authorise local governments with more autonomy. In 2014, besides 15 provinces where students took the uniformed national entrance exam, 16 provinces were allowed to determine the subjects for testing and design their own 
test papers (Liu 2015a). The power was further decentralised in the subsequent college admissions, featuring the shift from a centrally planned admission system under a planned economy to a free admission system under a socialist market economy ( $\mathrm{Li}$ and Bray 1992; Shen and Li 2003). Local governments were permitted to decide on the 'cut-off points' (minimal points for admission) for different types of universities within their jurisdictions (Liu 2015b). HEIs can adjust their own cut-off points and decide on the size of enrolment and proportion for each subject (Higher Education Law 1998, Act 32). Some universities were granted the privilege to admit students through channels in addition to Gaokao, such as the 'independent admission'; since 2003, selected universities can organise additional exams by themselves and lower the 'cut-off' Gaokao points for students passing those exams (Ministry of Education 2003a).

While reforms on college admission promise increasing autonomy to provincial governments and HEIs, the central government retains overarching control of Gaokao by constantly issuing regulations to supervise provincial entrance examinations and institutional independent admissions (such as Ministry of Education 2016b, c). One of the substantial influences imposed by government policies is the enrolment plan.

In China, university's enrolment plans are nested in the state's enrolment expansion policy. Under the motivation of economic modernisation and HE massification (Ngok 2008; Zha 2009), the state issued the Action Plan for Vitalizing Education in the 21st Century in 1998 and proclaimed an increase in university gross enrolment rate from $9.1 \%$ in 1997 to $15 \%$ by 2010 (Ministry of Education 1998). The Outline (2010) reiterated the significance of HE expansion, requiring the gross enrolment rate to reach $40 \%$ by 2020 . In response, all universities in China expanded their scale of enrolment, leading China's HE into the period of massification (Ngok 2008).

In addition, the government regulates enrolment quota for specific regions or admission channels through policy instruments. Aware of the geographical discrimination and local protectionism in HEIs' preferences over local students or students from developed provinces (mostly located in Eastern China) (Liu 2015b), the central government issued the Outline (2010), stipulating that new college enrolment plans should be in favour of western and central regions. Moreover, despite their conducting of 'independent admission', universities were restrained in their enrolment quotas of such admission channels (e.g. Ministry of Education 2003a). Among the 3.89 million students enrolled in college in 2015, only $0.28 \%$ were admitted through 'independent admissions' (Ministry of Education 2016e; National Bureau of Statistics of China 2016).

\section{Intervention in university and discipline structures}

The system-wide disciplinary restructuring under the influence of the Soviet Union model in the 1950s has greatly altered the landscape of HE in China (Yang 2000). The government continued to use techniques in this respect to influence the macro-structure of Chinese universities - one notable example is the launch of a decade-long HE institutional restructuring since 1992. This is, again, mostly done by publishing policy documents.

With several universities amalgamated with other colleges under the support of local governments, the MoE consolidated these experiences by holding four national forums respectively from 1994 to 1998 ( $\mathrm{Li} 2003$ ). In the process, two policy papers specifically emphasised four restructuring strategies - 'transfer of jurisdiction', 'joint construction between the central government and local governments', 'cooperation among institutions', and 
'institutional amalgamation' (Ministry of Education 1995; The Report 1998). The policy orientation, coupled with the promotion by the central and local governments, and certain individual institutions, produced an unprecedented restructuring of Chinese HE (Yang 2015). More than 900 universities, 31 provinces, and 50 central government's departments were involved; by 2000, 597 institutions turned into 267 universities through institutional amalgamation, and 367 universities originally belonged to various central ministries became around 250 universities under 'joint construction' between the $\mathrm{MoE}$ and local governments (Ministry of Education 2008).

This restructuring aligned with the lasting theme of HE reforms since the 1980s towards a decentralised state, strengthened provincial governments, and more autonomous HEIs. It ended the disciplinary and regional disintegration in HE and produced a group of comprehensive universities more responsive to the local needs. This kind of direct intervention, i.e. using policy orders to mandate and implement mergers and restructurings of HEIs, however, is rare nowadays. The state utilises a more tactful way to influence the disciplinary structure in HEIs, that is, by influencing the direction and preference of research in each discipline.

The state uses policy tools to attract talents to enter or excel in specific disciplinary fields. For example, the 'Thousand Talents Plan', started in 1998, featured China's effort in bringing in top overseas scholars to China. It gave selected candidates highly generous welfare and preferential policies. However, candidates were largely limited to those pursuing natural and applied sciences, especially high-tech related and emerging disciplines (The Recruitment Program of Global Experts 2018). This inevitably gave policy orientation to prospective scholars and institutions in deciding their targeted disciplines.

Furthermore, the government uses intermediaries, especially evaluative ones, supported by benchmarking and international rankings, to influence universities' strategic allocation of resources to specific disciplines. For instance, the Action Plan of Education Innovation 2003-2007 explicitly called for the building of 'a system to evaluate the teaching quality of all HEIs every five years' (Ministry of Education 2003b). The introduction of Evaluation of University Baccalaureate Programmes Project in 2002 and Higher Education Evaluation Centre in 2004 signalled a new stage of systematic evaluation in Chinese HE (Li and Yang 2014). Based on governmental evaluations, the recent 'double first-class program' highlighted the development of a range of disciplines at 140 selected universities (Ministry of Education et al. 2017). It replaced the previous ' 985 ' and ' 211 ' programs, which only featured the building of world-class universities (China Academic Degrees and Graduate Education Information 2009, 2012), and called for fostering both world-class universities and first-class disciplines. The performance-based evaluation of disciplines and its anchor to national and international disciplinary rankings will 'inevitably link to resources allocation in HE' (Tian 2016), which may lead to the restructuring of disciplines voluntarily conducted by universities.

\section{Intervention in curriculum and ideological education}

Since the 1980s, the state is gradually withdrawing from intervening in curriculum and pedagogical practices of universities. The MoE and the Academic Degree Committee of the State Council still publish guidelines on the categorisation of subjects, disciplines, and academic degrees, but the major power to determine the content and procedure remain in the hands of institutions and individuals; the Higher Education Law entitled HEIs to 'act on their own in offering and readjusting the branches of learning and specialised subjects' (1998, article 33). 
However, the state retains firm control of the ideological and political education in universities. It strengthened the ideopolitical education through strategies such as making it mandatory in every stage of tertiary education, training a group of professionalised and specialised teachers, and improving the appeal of course contents (Wang 2013). In addition to Chinese universities, Sino-foreign joint universities, a fast developing form of $\mathrm{HE}$ internationalisation in China, were also required to provide similar ideopolitical courses about the constitution, laws, civic virtue, and the situation of China (State Council 2003). President $\mathrm{Xi}$ also emphasised the importance of ideopolitical education, which 'must be integrated into the whole process of university education' (Xinhua News Agency 2013, 2016, 2018). Consequently, the state aimed to make universities 'strongholds' of the party, and teachers and students supporters of the party's leadership (Phillips 2016).

In sum, access to HE, disciplinary structure, and curriculum and ideology are all essential aspects of higher education development. As demonstrated in the three cases outlined above, they clearly form an integral part of the state's governance over universities, through strategic use of the policy lever. As compared with the law, such a policy instrument merits more flexibility and timeliness with the possibility to be used towards targeted problems.

\section{Governance through finance}

Finance has gained growing prominent in the Chinese context, particularly with China's transition from a planned economy to a socialist market economy. The state becomes increasingly tactful in using such governance instrument to steer HE, as demonstrated by the changing policy of funding and tuition fees.

\section{Funding and grants}

The funding bases of HE in China become continuously diversified through the state's efforts in bringing in various stakeholders. In the 1980s, almost all universities were public universities, administrated and financed by either the MoE, ministries of central governments, or provincial education commissions (Min 1991). The situation changed when the state decided to step back and encourage the growth of the private sector. The Higher Education Law explicitly stated that 'the state encourages enterprises, institutions, public organizations or groups and individuals to invest in HE' (1998, article 60). This stance of embracing investment from non-state sectors was reiterated in several policies such as the Outline (2010). As a result, while government appropriation remained the most important funding source for HEIs, its relative proportion in the total HE funding was gradually decreasing: from more than $90 \%$ in the late 1980s (Min 1991) to 79\% in 1996 (National Bureau of Statistics of China 2007), then to $58 \%$ in 2011 (National Bureau of Statistics of China 2013). Consequently, universities started to venture into marketing and industrial fields to generate revenue (Mok 2002), and the number of private universities has been expanding from 55 in 2000 to 747 in 2017 (Ministry of Education 2001, 2017).

It is argued that diversified funding sources could improve and protect university autonomy (Goedegebuure et al. 1994). However, although the Chinese government gradually withdrew from direct monetary provision to universities, it has become a 'market manager' (Yang et al. 2006 , p. 580) and has taken different forms of supervisions such as targeted and performancebased funding schemes. 
The state exercises macro control over higher education quality through national funding schemes. Funding schemes such as the 'Project 211' and 'Project 985' were initiated in the late 1990s to enhance the quality of selected universities and support them to become 'world-class universities' (China Academic Degrees and Graduate Education Information 2009, 2012). Universities selected were guaranteed with elite status and significant funding privileges (Hayhoe et al. 2005; Zha 2009). For instance, the government's science and research appropriation per each '211' university in 2015 was 12.5 times of that per each 'non-211' university (Ministry of Education 2016a, p. 14). Those projects employed ex-ante assessment methods on quantitative and objective criteria such as staffing, facilities, and research. Therefore, to get the funding privileges, universities had strived to improve their profile through enhancing quality and research capacities (Mok 2002).

A significant shift from ex-ante assessment to performance-based funding is indicated by the recent 'double first-class program'. The central government's funding for 'double firstclass' universities will fluctuate based on continuous evaluations on universities' performance (State Council 2015). By introducing performance-based funding schemes, the state inevitably increases universities' dependence on the central government and introduces more accountability measures into HE (Yang et al. 2006).

\section{Tuition fees}

Before the late 1980s, all students in China attended universities for free. However, with the development of the socialist market economy and the growth of cost through HE expansion, the state began to share the cost with the local governments, communities, HEIs, students' families, and individual students (Ministry of Education 2002; Wang 2001). In 1992, universities were officially approved by the MoE (then called the State Education Commission) to enrol up to $25 \%$ fee-paying students; in 1997 , the tuition fee policy came into force for all students (Mok 2002).

Although universities are granted the right to collect tuition fees, the state continued to supervise tuition fees to prevent them from soaring, and guarantee the affordability and accessibility of HE. For example, the MoE demanded tuition fees to reflect 'the perstudent operational costs of the institution, the appropriation from the government, local economic development and household income' (Wang 2009, p. 2). Accordingly, provincial governments set the tuition fee levels for local HEIs (Ministry of Education 2002). Moreover, the central government repeatedly warned universities against raising tuition fees or charging extra fees from students (for instance Ministry of Education et al. 2005, 2006, 2012). In 2007, the State Council published a policy to prohibit all universities from raising their tuition fees and accommodation fees for the following 5 years (State Council 2007).

\section{Concluding remarks: the state's governance of HE}

This paper investigates the state's changing governance of HE in China between 1978 and 2018 with a proposed analytic framework. The three forms of governance instruments represent different governance strategies over HE practices, ranging from direct and visible control, such as laws and policy orders, to indirect tools such as targeted funding; from intervening institutional internal affairs, such as using legal powers to intervene in its 
governance structure, to regulating the university's external management, such as adjusting the university and disciplinary structures. By examining three governance instruments and seven types of institutional demonstrations, this paper reveals that the logics of HE governance in China have moved from direct controls to indirect supervision, with the state adhering essential powers over HEIs.

The study argues that China is no exception to the world's trend of transforming from an interventionist to evaluative governance with more employment of indirect instruments. Over the past three decades, it is moving from lawlessness to using legislation to reduce the arbitrariness in rulers' decision-making. In addition, the state constantly uses policies to influence the direction and practices of HE in areas such as college admission, disciplinary structure, and curriculum. Financially speaking, the state is transforming from the sole funding provider to a market manager, supervising HEIs through performance-based funding. With the state's attempt to 'step back', arguably, it is conceding more autonomy and freedom to universities in areas that are traditionally intervened through direct strategies. Those can be regarded as 'operational autonomy' to encourage better performance of HEIs, or being 'instrumental in aligning them to governmental goals and performance expectations' (Enders et al. 2013, p. 21). This trend corresponds to the broader social, political, and economic changes in China since the Reform and Opening-up in 1978, in particular, the transformation from a planned economy to a socialist market economy and the shift towards the 'rule-of-law'.

However, this study argues that essential powers are still tightly held in the hands of the state, such as the heavy political and ideological imprints in university curriculum and culture, and the appointment of presidents and party secretaries. Such situation sits in the context of both the political arrangement and state configuration of China.

In particular, the gripping ideological control can be understood through the symbiotic relationship between knowledge and power. The political power legitimates 'knowledge and the existing modes of knowledge production' by setting boundaries of disciplines and structures (Weiler 2001, p. 34). On the other hand, knowledge provides legitimacy for nation states and its authority (Weiler 2001). As articulated by Engels (1994), the state presents itself 'as the first ideological power over man'. In order to intervene in HE, the state has to foremost establish its legitimacy and challenge the traditional liberal ideal of universities (Salter and Tapper 1994); this legitimacy could come from the 'economic ideology of education' (p. 20) or the pursuit of national identity constituted by claimed common social interests. Hence, the state constantly and strategically uses such governance instruments as the critical source for the legitimisation of its political authority.

Although it may be perceived as problematic when benchmarked against western models, the unique case of China corresponds to the long-standing function and mission of Chinese public universities as part of the state apparatus in training talents for national interests and state revitalisation (Law 2014). It also reflects the influence of Confucian values on scholars, which associate the pursuit of knowledge to social and national interests (Zha and Shen 2018). In addition, Chinese scholars have been accustomed to balancing their roles as both political and academic figures (Du 2018). While Chinese scholars and university practitioners strive for autonomy to realise their academic pursuits, they also hold the desire and responsibility to support the state (Zha 2012; Zha and Hayhoe 2014). The paradoxical 'dancing with the chain' may best capture the Chinese version of university autonomy and academic freedom. It is well aligned with the argument proposed in the study and enbles the incorporation of HEIs into nationbuilding. 
This paper does not aim to exhaustively name all kinds of cases on China's HE governance. Particularly, the state's governance over private HEIs and international activities in China could be of interests to future studies. By proposing a framework conceptualising China's HE governance and applying it in the country's 30-year practice, this study is able to unpack the state's mixed (changing) use of governance strategies and instruments over universities; thus contributing to the theoretical and empirical understandings and practices of HE governance.

\section{Compliance with ethical standards}

Conflict of interest The authors declare that they have no conflict of interest.

Open Access This article is distributed under the terms of the Creative Commons Attribution 4.0 International License (http://creativecommons.org/licenses/by/4.0/), which permits unrestricted use, distribution, and reproduction in any medium, provided you give appropriate credit to the original author(s) and the source, provide a link to the Creative Commons license, and indicate if changes were made.

\section{References}

Berdahl, R. O. (1990). Academic freedom, autonomy, and accountability in British universities. Studies in Higher Education, 15(2), 169-180.

Berdahl, R. O., Altbach, P. G., \& Gumport, P. J. (2005). The contexts of American higher education. In P. G. Altbach, R. O. Berdahl, \& P. J. Gumport (Eds.), American higher education in the twenty-first century: social, political, and economic challenges (pp. 1-10). Baltimore and London: Johns Hopkins University Press.

Boer, H. D., \& File, J. (2009). Higher education governance reforms across Europe. Brussels: ESMU.

Capano, G., \& Turri, M. (2016). Same governance template but different agencies. Higher Education Policy, $30(2), 225-243$.

China Academic Degrees \& Graduate Education Information. (2009). An introduction to 'Project 211' (in Chinese). http://www.cdgdc.edu.cn/xwyyjsjyxx/xwbl/zdjs/211gc/257660.shtml. Accessed 12 Dec 2016.

China Academic Degrees \& Graduate Education Information. (2012). An introduction to 'Project 985' (in Chinese). http://www.cdgdc.edu.cn/xwyyjsjyxx/xwbl/zdjs/985gc/274804.shtml. Accessed 12 Dec 2016.

Clark, B. R. (1983). The higher education system: academic organization in cross-national perspective. Berkeley: University of California Press.

Communist Party of China Central Committee. (1985). The decision of the reform of education system by the Central Committee of the Communist Party of China (in Chinese). http://www.moe.edu. $\mathrm{cn} /$ publicfiles/business/htmlfiles/moe/moe_177/200407/2482.html. Accessed 12 Dec 2016.

Crewe, I. (2013). State-academy relations in the United Kingdom, 1960-2010. In R. Goodman, T. Kariya, \& J. Taylor (Eds.), Higher education and the state: changing relationships in Europe and East Asia (pp. 79-94). Oxford: Symposium Books.

De Boer, H., Enders, J., \& Schimank, U. (2008). Comparing higher education governance system in four European countries. In N. C. Soguel \& P. Jaccard (Eds.), Governance and performance of education systems (pp. 35-54). Dordrecht: Springer.

Du, X. (2018). Role split phenomenon of academic staff in Chinese higher education: a case study of Fudan University. Higher Education, 75, 997-1013.

Edirisooriya, G. (2003). A historical analysis of the state-university relationship: a case study of the University of Delaware, USA. Journal of the History of Education Society, 32(4), 367-383.

Education Law of the People's Republic of China. (1995). http://en.moe.gov.cn/Resources/Laws_and Policies/201506/t20150626_191385.html. Accessed 12 Dec 2016.

Enders, J., de Boer, H., \& Weyer, E. (2013). Regulatory autonomy and performance: the reform of higher education re-visited. Higher Education, 65, 5-23.

Engels, F. (1994). Ludwig Feuerbach and the end of classical German philosophy. https://www.marxists. org/archive/marx/works/1886/ludwig-feuerbach/. Accessed 12 Dec 2016.

Ferlie, E., Musselin, C., \& Andresani, G. (2008). The steering of higher education systems: a public management perspective. Higher Education, 56(3), 325-348. 
Gallagher, M. (2001). Modern university governance: a national perspective. Proceedings from a Conference organised by Manning Clark House and The Australia Institute: The idea of a university: enterprise or academy? (pp. 49-57). Canberra: The Australia Institute and Manning Clark House.

Goedegebuure, L., Kaiser, F., Maassen, P., Meek, L., van Vught, F., \& de Weert, E. (Eds.). (1994). Higher education policy: an international comparative perspective. Oxford: Pergamon Press.

Halstead, J. M., \& Zhu, C. (2009). Autonomy as an element in Chinese educational reform: a case study of English lessons in a senior high school in Beijing. Asia Pacific Journal of Education, 29(4), 443-456.

Hawkins, J. N. (2000). Centralization, decentralization, recentralization - education reform in China. Journal of Educational Administration, 38(5), 442-454.

Hayhoe, R., \& Liu, J. (2010). China's universities, cross-border education, and dialogue among civilizations. In D. Chapman, W. K. Cummings, \& G. A. Postiglione (Eds.), Crossing borders in East Asian higher education (pp. 77-102). Dordrecht: Springer.

Hayhoe, R., Zha, Q., \& Lin, R. (2005). Becoming world class: Chinese universities facing globalization and internationalization. Fudan Education Forum, 3(3), 59-65.

Higher Education Law of the People's Republic of China (in Chinese). (1998). http://www.npc.gov. $\mathrm{cn} / \mathrm{wxzl} / \mathrm{wxzl} / 2000-12 / 05 / \mathrm{content} 4712 . \mathrm{htm}$. Accessed 20 Dec 2016.

Higher Education Law of the People's Republic of China (in Chinese). (2015). http://www.npc.gov. cn/npc/cwhhy/12jcwh/2015-12/28/content_1957555.htm. Accessed 20 Dec 2016.

Jing, Y. (2013). 'Documentary politics' in China. In National School of Development of Peking University (Ed.), The boundaries of public opinions (in Chinese). Shanghai: Shanghai People Publishing House.

Kazamias, A. M. (2009). Paideia and Politeia: education, and the polity/state in comparative education. In R. Cowen \& A. M. Kazamias (Eds.), International handbook of comparative education (pp. 161-168). Dordrecht: Springer Netherlands.

Kogan, M., \& Hanney, S. (2000). Reforming higher education. London: Jessica Kingsley Publishers.

Law, W. (2002). Legislation, education reform and social transformation: the People's Republic of China's experience. International Journal of Educational Development, 22, 579-602.

Law, W. (2014). Understanding China's curriculum reform for the 21st century. Journal of Curriculum Studies, 46(3), 332-360.

Li, L. (2003). On education: interviews with Li Lanqing. Beijing: People's Education Press.

Li, S., \& Bray, M. (1992). Attempting a capitalist form of financing in a socialist system: student loans in the People's Republic of China. Higher Education, 23(4), 375-387.

Li, M., \&Yang, R. (2014). Governance reforms in higher education: a study of China. UNESCO: International Institute for Educational Planning (IIEP).

Liu, H. (2015a). The historical logic behind the shift from decentralization to centralization in designing Gaokao. http:/www.moe.gov.cn/publicfiles/business/htmlfiles/moe/s8623/201503/184748.html. Accessed 12 Dec 2016.

Liu, Y. (2015b). Geographical stratification and the role of the state in access to higher education in contemporary China. International Journal of Educational Development, 44, 108-117.

Marginson, S. (1999). After globalization: emerging politics of education. Journal of Education Policy, 14(1), 19-31.

McDaniel, O. (1996). The paradigms of governance in higher education systems. Higher Education Policy, 9(2), 137-158.

Min, W. (1991). Higher education finance in China: current constraints and strategies for the 1990s. Higher Education, 21(2), 151-161.

Ministry of Education. (1995). Suggestions of deepening higher education structural reform (in Chinese). http://govinfo.nlc.gov.cn/gzsfz/zfgb/199509/201108/t20110818_959548.html. Accessed 12 Dec 2016.

Ministry of Education. (1998). Action plan for vitalizing education in the 21st century (in Chinese). http://www. moe.gov.cn/publicfiles/business/htmlfiles/moe/moe_177/200407/2487.html. Accessed 12 Dec 2016.

Ministry of Education. (2001). An analysis of the development of private higher education in China (in Chinese). http://www.moe.gov.cn/jyb_sjzl/moe_364/moe_369/moe_408/tnull_4744.html. Accessed 12 Dec 2016.

Ministry of Education. (2002). Introduction to the reform of fees in higher education institutions (in Chinese). http://www.moe.gov.cn/publicfiles/business/htmlfiles/moe/moe_163/200409/3949.html. Accessed 12 Dec 2016.

Ministry of Education. (2003a). Notice of the Ministry of Education on reforms of higher education institutions' independent admission (in Chinese). http://www.moe.gov.cn/srcsite/A15/moe_776/s3110/200302 /t2003022789058.html. Accessed 12 Dec 2016.

Ministry of Education. (2003b). Action plan of education innovation 2003-2007 (in Chinese). http://www.moe. edu.cn/publicfiles/business/htmlfiles/moe/moe 177/200407/2488.html. Accessed 12 Dec 2016.

Ministry of Education, State Council Office of Redressing Malpractices, Ministry of Supervision, National Development and Reform Commission, Ministry of Finance, National Audit Office, \& Press and Publication Administration. (2006). Opinions of Ministry of Education and other six ministries on regulating misbehaviors in fee collections in 2006 (in Chinese). http://www.moe.gov.cn/srcsite/A25/s3144/200604 /t20060406_81023.html. Accessed 12 Dec 2016. 
Ministry of Education. (2008). Reform on the higher education system (in Chinese). http://www.moe.gov. cn/publicfiles/business/htmlfiles/moe/moe 2442/200810/39569.html. Accessed 12 Dec 2016.

Ministry of Education. (2016a). In Ministry of Education. Department of Science and Technology (Ed.), 2015 Statistics of science and technology (in Chinese). Beijing: Higher Education Press.

Ministry of Education. (2016b). Notice of Ministry of Education on the 2016 higher education institutions' admission (in Chinese). http://www.moe.gov.cn/srcsite/A15/moe_776/s3258/201603/t20160307_232202. html. Accessed 12 Dec 2016.

Ministry of Education. (2016c). Opinions of Ministry of Education on further strengthening the information disclosure and supervision of higher education institutions' independent admission (in Chinese). http://www. moe.gov.cn/srcsite/A15/moe_776/s3110/201604/t20160411_237551.html. Accessed 12 Dec 2016

Ministry of Education. (2016d). Publication of the examination outlines for 2017 national college entrance examination (in Chinese). http://www.moe.gov.cn/jyb_xwfb/gzdt_gzdt/s5987/201610/t20161014_284883. html. Accessed 12 Dec 2016.

Ministry of Education. (2016e). Annual report of government information from the Ministry of Education 2015 (in Chinese). http://www.moe.gov.cn/srcsite/A01/s7048/201603/t20160328 235659.html. Accessed 12 Dec 2016.

Ministry of Education. (2017). The list of higher education institutions (in Chinese). http://www.moe.gov. cn/srcsite/A03/moe_634/201706/t20170614_306900.html. Accessed 20 February 2018.

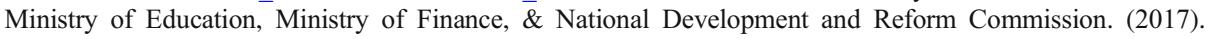 Releasing the lists of 'world first-class universities' and 'world first-class disciplines' (in Chinese). http://www.xinhuanet.com/politics/2017-09/21/c_1121701051.htm. Accessed 20 February 2018.

Ministry of Education, State Council Office of Redressing Malpractices, Ministry of Supervision, National Development and Reform Commission, Ministry of Finance, National Audit Office, \& Press and Publication Administration. (2005). Opinions of Ministry of Education and other six ministries on regulating misbehaviors in fee collections in 2005 (in Chinese). http://www.moe.gov.cn/srcsite/A25/s3144/200504 /t20050401_81025.html. Accessed 12 Dec 2016.

Ministry of Education, State Council Office of Redressing Malpractices, Ministry of Supervision, National Development and Reform Commission, Ministry of Finance, National Audit Office, \& Press and Publication Administration. (2012). Opinions of Ministry of Education and other six ministries on regulating misbehaviors in fee collections in 2012 (in Chinese). http://www.moe.gov.cn/srcsite/A01/s7048/201204 /t20120428 171881.html. Accessed 12 Dec 2016.

Mok, K. H. (2002). Policy of decentralization and changing governance of higher education in post-Mao China. Public Administration and Development, 22(3), 261-273.

Mok, K. H., \& Lee, M. H. H. (2003). Globalization or glocalization? Higher education reforms in Singapore. Asia Pacific Journal of Education, 23(1), 15-42.

National Bureau of Statistics of China. (2007). China statistical yearbook 2007. http://www.stats.gov. cn/english/Statisticaldata/AnnualData/. Accessed 20 Feb 2018.

National Bureau of Statistics of China. (2013). China statistical yearbook 2013 (in Chinese). http://www.stats. gov.cn/tjsj/ndsj/2013/indexeh.htm. Accessed 20 Feb 2018.

National Bureau of Statistics of China. (2016). China statistical yearbook 2016 (in Chinese). http://www.stats. gov.cn/tjsj/ndsj/2016/indexeh.htm. Accessed 20 Feb 2018.

Ngok, K. (2007). Chinese education policy in the context of decentralization and marketization: evolution and implications. Asia Pacific Education Review, 8(1), 142-157.

Ngok, K. (2008). Massification, bureaucratization and questing for 'world-class' status higher education in China since the mid-1990s. International Journal of Educational Management, 22(6), 547-564.

Pan, S. (2009). University autonomy, the state, and social change in China. Hong Kong: Hong Kong University Press.

Phillips, T. (2016). China universities must become communist party 'strongholds'. Guardian, 2016-12-09. https://www.theguardian.com/world/2016/dec/09/china-universities-must-become-communist-partystrongholds-says-xi-jinping. Accessed 20 Dec 2016.

Salter, B., \& Tapper, T. (1994). The state and higher education. Ilford: Woburn Press.

Schwarz, S., \& Westerheijden, D. (2004). Accreditation and evaluation in the European higher education area. Dordrecht: Kluwer Academic Press.

Shen, H., \& Li, W. (2003). A review of the student loans scheme in China. Bangkok: UNESCO Bangkok.

Southern University of Science and Technology. (2018). Milestones (in Chinese). http://www.sustc.edu.cn/shiji. Accessed 20 Dec 2018.

State Council. (2003). Regulations of the People's Republic of China on Chinese-foreign cooperation in running schools. http://www.crs.jsj.edu.cn/news/index/3. Accessed 20 Dec 2016.

State Council. (2007). Opinions of the State Council on establishing and improving financial aid policy system for students with financial difficulties in higher education institutions, higher and secondary vocational schools (in Chinese). http://www.gov.cn/zwgk/2007-05/23/content_623615.htm. Accessed 20 Dec 2016. 
State Council. (2015). The plan of building world-class universities and first-class disciplines (in Chinese). http:/www.moe.gov.cn/jyb_xxgk/moe_1777/moe_1778/201511/t20151105_217823.html. Accessed 12 Dec 2016.

The outline of China's national plan for medium and long-term education reform and development (2010-2020). (2010). https://internationaleducation.gov.au/News/newsarchive/2010/Documents/China_Education Reform_pdf.pdf. Accessed 12 Dec 2016.

The Recruitment Program of Global Experts. (2018). http://www.1000plan.org/qrih/section/2?m=rcrd. Accessed 20 Dec 2018.

The report on the work of the government in year 1998 (in Chinese). http://www.gov.cn/test/2006-02/16 /content 201129.htm. Accessed 12 Dec 2016.

Tian, Y. (2016). Thoughts on the 4th round subject evaluation. Guangming Daily, 2016-11-22.

Wang, X. (2001). A policy analysis of the financing of higher education in China: two decades reviewed. Journal of Higher Education Policy and Management, 23(2), 205-217.

Wang, J. (2009). Higher education finance and cost sharing profiles by country: China. The International Comparative Higher Education and Finance Project. http://gse.buffalo. edu/org/inthigheredfinance/files/Country Profiles/Asia/China.pdf. Accessed 12 Dec 2016.

Wang, X. (2010a). Higher education as a field of study in China: defining knowledge and curriculum structure. Plymouth: Lexington Books.

Wang, L. (2010b). Higher education governance and university autonomy in China. Globalisation, Societies and Education, 8(4), 477-495.

Wang, Q. (2013). Strengthening and professionalizing political education in China's higher education. Journal of Contemporary China, 22(80), 332-350.

Weiler, H. N. (2001). Knowledge, politics, and the future of higher education: critical observations on a worldwide transformation. In R. Hayhoe \& J. Pan (Eds.), Knowledge across cultures: a contribution to dialogue among civilizations (pp. 25-43). Hong Kong: University of Hong Kong.

Wu, G. (1995). 'Documentary politics': hypotheses, process and case studies. In C. L. Hamrin \& S. Zhao (Eds.), Decision-making in Deng's China: perspectives from insiders. Armonk: M.E. Sharpe.

Xinhua News Agency. (2013). Xi Jinping: ideological work is an extremely important task for the Communist Party of China (in Chinese). http://www.xinhuanet.com//politics/2013-08/20/c_117021464.htm. Accessed 20 Dec 2016.

Xinhua News Agency. (2016). Xi Jinping: integrate ideo-political education into the whole education process (in Chinese). http://www.xinhuanet.com//politics/2016-12/08/c_1120082577.htm. Accessed 20 Dec 2016.

Xinhua News Agency. (2018). Xi Jinping: adhere to the path of socialist education with Chinese characteristics and cultivate all-round socialist builders and successors (in Chinese). http://www.xinhuanet. com/politics/leaders/2018-09/10/c_1123408400.htm. Accessed 20 Dec 2018.

Yang, R. (2000). Tensions between the global and the local: a comparative illustration of the reorganization of China's higher education in the 1950s and 1990s. Higher Education, 39(3), 319-337.

Yang, R. (2015). Institutional mergers in Chinese higher education. In A. Curaj, L. Georghiou, J.C. Harper, \& E.E. Polak (Eds.), Mergers and alliances in higher education: International practice and emerging opportunities (pp. 123-144). Dordrecht: Springer International Publishing.

Yang, R., Vidovich, L., \& Currie, J. (2006). 'Dancing in a cage': changing autonomy in Chinese higher education. Higher Education, 54(4), 575-592.

Zha, Q. (2009). Diversification or homogenization: how governments and markets have combined to (re)shape Chinese higher education in its recent massification process. Higher Education, 58(1), 41-58.

Zha, Q. (2011). China's move to mass higher education in a comparative perspective. Compare: A Journal of Comparative and International Education, 41(6), 751-768.

Zha, Q. (2012). Intellectuals, academic freedom, and university autonomy in China. In H. Schuetze, W. Bruneau, \& G. Grosjean (Eds.), University governance and reform: policy, fads and experience in international perspective (pp. 209-224). New York: Palgrave Macmillan.

Zha, Q., \& Hayhoe, R. (2014). The 'Beijing Consensus' and the Chinese model of university autonomy. Frontiers of Education in China, 9(1), 42-62.

Zha, Q., \& Shen, W. (2018). The paradox of academic freedom in the Chinese context. History of Education Quarterly, 58(03), 447-452.

Publisher's note Springer Nature remains neutral with regard to jurisdictional claims in published maps and institutional affiliations. 